\title{
TASK 6.7.2 - IMPROVED CORROSION RESISTANCE OF ALUMINA REFRACTORIES
}

\author{
Final Topical Report \\ for the period January 1, 1997, through June 30, 1998
}

Prepared for:

Federal Energy Technology Center

AAD Document Center

U.S. Department of Energy

PO Box 10940, MS 921-143

Pittsburgh, PA 15236

Cooperative Agreement No. DE-FC21-93MC30097-40

Performance Monitor: Udaya Rao

Prepared by:

John P. Hurley Patricia L. Kleven

Energy \& Environmental Research Center University of North Dakota

PO Box 9018

Grand Forks, ND 58202-9018 


\section{DOE DISCLAIMER}

This report was prepared as an account of work sponsored by an agency of the United States Government. Neither the United States Government, nor any agency thereof, nor any of their employees makes any warranty, express or implied, or assumes any legal liability or responsibility for the accuracy, completeness, or usefulness of any information, apparatus, product, or process disclosed or represents that its use would not infringe privately owned rights. Reference herein to any specific commercial product, process, or service by trade name, trademark, manufacturer, or otherwise does not necessarily constitute or imply its endorsement, recommendation, or favoring by the United States Government or any agency thereof. The views and opinions of authors expressed herein do not necessarily state or reflect those of the United States Government or any agency thereof.

Available to the public from the National Technical Information Service, U.S. Department of Commerce, 5285 Port Royal Road, Springfield, VA 22161; phone orders accepted at (703) 487-4650.

\section{ACKNOWLEDGMENT}

This report was prepared with the support of the U.S. Department of Energy (DOE) Federal Energy Technology Center, Cooperative Agreement No. DE-FC21-93MC30097. However, any opinions, findings, conclusions, or recommendations expressed herein are those of the author(s) and do not necessarily reflect the views of DOE.

\section{EERC DISCLAIMER}

LEGAL NOTICE This research report was prepared by the Energy \& Environmental Research Center (EERC), an agency of the University of North Dakota, as an account of work sponsored by DOE. Because of the research nature of the work performed, neither the EERC nor any of its employees makes any warranty, express or implied, or assumes any legal liability or responsibility for the accuracy, completeness, or usefulness of any information, apparatus, product, or process disclosed or represents that its use would not infringe privately owned rights. Reference herein to any specific commercial product, process, or service by trade name, trademark, manufacturer, or otherwise does not necessarily constitute or imply its endorsement or recommendation by the EERC. 


\section{TABLE OF CONTENTS}

1.0 INTRODUCTION $\ldots \ldots \ldots \ldots \ldots \ldots \ldots \ldots \ldots \ldots \ldots \ldots \ldots \ldots \ldots \ldots$

2.0 OBJECTIVES $\ldots \ldots \ldots \ldots \ldots \ldots \ldots \ldots \ldots \ldots \ldots \ldots \ldots \ldots \ldots \ldots \ldots$

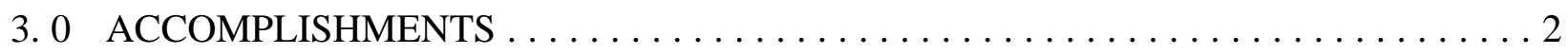

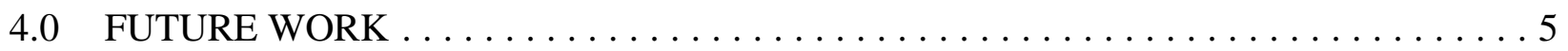

\section{LIST OF FIGURES}

1 Schematic of dynamic slagging application furnace $\ldots \ldots \ldots \ldots \ldots \ldots \ldots \ldots$

2 SEM image of sample modified with $1 \%$ lanthana $\ldots \ldots \ldots \ldots \ldots \ldots$

3 Yttria-alumina-garnet found in sample modified with $1 \%$ yttria $\ldots \ldots \ldots \ldots \ldots$

4 SEM image showing increased number of individual crystals in sample modified

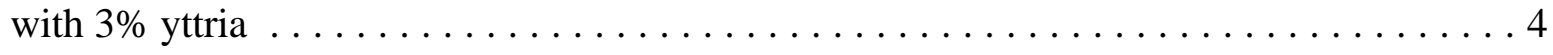

5 Graph comparing recession with time for sample of Plicast 99 modified with $1 \%$ yttria and

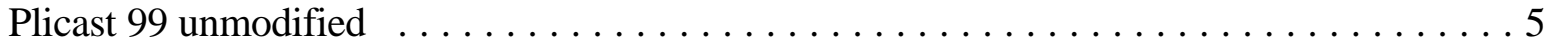




\section{TASK 6.7 - IMPROVED CORROSION RESISTANCE OF ALUMINA REFRACTORIES}

\subsection{INTRODUCTION}

In order to increase the efficiency of advanced coal-fired power systems, higher working fluid temperatures must be reached. Some system surfaces will have to be protected by covering them with corrosion-resistant refractories. Corrosion is the degradation of the material surfaces or grain boundaries by chemical reactions with melts, liquids, or gases causing loss of material and consequently a decrease in strength of the structure. In order to develop methods of reducing corrosion, the microstructure that is attacked must be identified along with the mechanism and rates of attack. Once these are identified, methods for reducing corrosion rates can be developed.

In order to determine the reactivity of a refractory to the slag or glass in most industrial applications, various slag tests have been developed. The most common are the cup slag test, drip slag test (ASTM C768), gradient slag test, rotary slag test (ASTM C874), and the dip-and-spin test. Among these tests, the cup slag test is the only static test method and most commonly used. In this study, we compared the rates of corrosion of castable alumina refractory samples modified with rare earth oxides (REOs) using the static test method, then compared the static test data with data from our dynamic corrosion test method.

\subsection{OBJECTIVES}

Since refractory exposed surface area is a prime concern in corrosion, the initial focus of this project is to try to improve the near surface of the grains and bond phase between grains. Bonding phases normally have a lower melting point and lower corrosion resistance than does the bulk of the material. The best conventional high-alumina refractories are bonded by mullite or alumina itself.

To change the bond characteristics to a more corrosion-resistant material compatible with the alumina matrix, phase diagrams are useful. It is well established that alumina forms a complete series of crystalline solutions with the lanthanide or REOs. Within the lanthanide- alumina $\left(\operatorname{Ln}_{2} \mathrm{O}_{3}\right.$ $\left./ \mathrm{Al}_{2} \mathrm{O}_{3}\right)$ phase diagrams, several compounds have been identified, the relative stability of which depends on the individual lanthanide or REO present. For example, the perovskites, $\mathrm{LnAl}_{2} \mathrm{O}_{3}$, where $\mathrm{Ln}$ is, for example, $\mathrm{Y}, \mathrm{La}, \mathrm{Nd}, \mathrm{Ce}, \mathrm{Pr}, \mathrm{Pm}, \mathrm{Sm}$, or $\mathrm{Eu}$, and the garnets, $\mathrm{Ln}_{3} \mathrm{Al}_{5} \mathrm{O}_{12}$, where $\mathrm{Ln}$ is, for example, $\mathrm{Y}, \mathrm{Tb}, \mathrm{Dy}, \mathrm{Er}, \mathrm{Tm}, \mathrm{Yb}$, or $\mathrm{Lu}$, are all stable high- melting-point materials. It is the objective of this study to evaluate the use of these REOs to increase the resistance to corrosion of the bonding phase in castable alumina refractories and to determine the mechanism of protection. 


\section{0 ACCOMPLISHMENTS}

As described in the previous semiannual report, a preliminary screening test matrix was developed to study the effects of selected REOs on two experimental high-alumina castable refractories from the Plibrico Company, Illinois. The castables were Plicast 98 and Plicast 99, named for the percentage of alumina in each. Two levels of additives were used, the minimum being $0.25 \%$ and the maximum being $1 \%$ REOs on a weight percent basis. The test method used was the standard static cup slag test.

For the static corrosion test, $11 \mathrm{~g}(0.024 \mathrm{lb})$ of Illinois No.6 coal slag was placed into the refractory test sample and placed into the furnace at $1500^{\circ} \mathrm{C}\left(2732^{\circ} \mathrm{F}\right)$ for 100 hours. The most corrosion-resistant mixture from the static corrosion test was then tested using the recently developed dynamic corrosion test in which fresh refractory blocks are exposed to a continuous slag flow of about $51 \mathrm{~g}(0.11 \mathrm{lb})$ for an hour through a 1 -cm-diameter semicircular channel. Figure 1 shows a schematic representation of the experimental dynamic slag corrosion testing system.

During the latest reporting period, scanning electron microscopy (SEM) was used to determine the depth of slag penetration and to look for structural changes that were contributions of the REOs. The maximum depth of slag penetration into the blocks is the location at which measurable concentrations of the major slag constituents, $\mathrm{Si}, \mathrm{Ca}$, and $\mathrm{Fe}$, were found in the blocks as determined by elemental mapping. It was hoped that the REO additions would modify the matrix and near surface of the grain boundaries where the dissolution tends to occur, reducing the diffusion rates of the corrodents, or would possibly form a continuous passive layer resistant to slag corrosion.

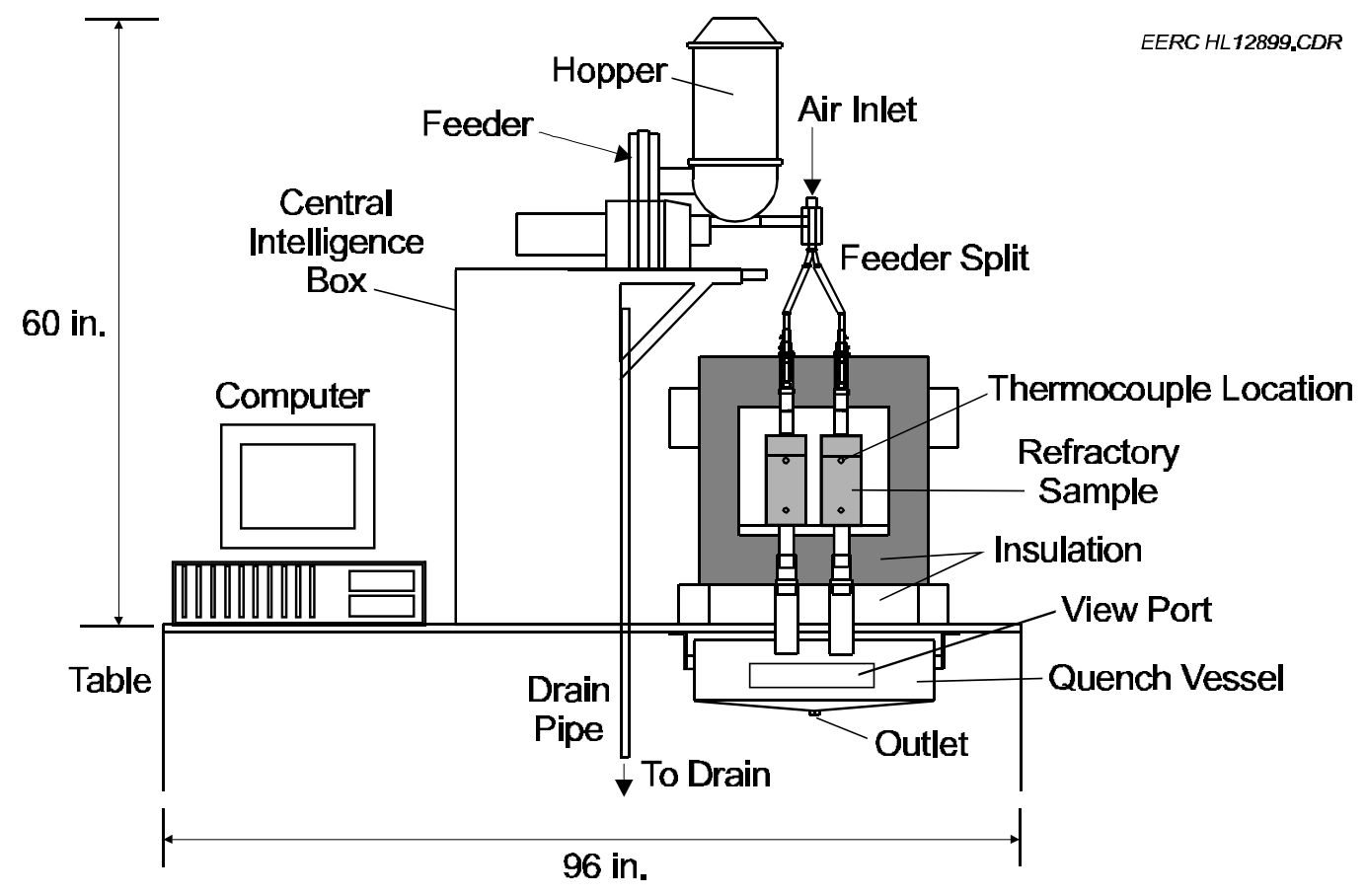

Figure 1. Schematic of dynamic slagging application furnace. 
We found that in the samples modified with $1 \%$ additions of the REOs neodymia and lanthana, the silica from the slag combined with the REO to enhance the slag diffusion into the refractory. Figure 2 is a SEM image taken at the maximum depth of penetration $(16 \mathrm{~mm})$ on the sample modified with $1 \%$ addition of lanthana. The chemical analysis in this area showed the composition to be mainly alumina (35 wt\%), lanthana (16 wt\%), silica (7 wt\%), and lesser amounts of calcium and sodium. The sample modified with a $1 \%$ addition of neodymia had a depth of penetration $(15 \mathrm{~mm})$ similar to that for the sample modified with lanthana. The sample modified with a total of $3 \mathrm{wt} \%$ (8 grams each of lanthana, neodymia, and yttria) had visible structural damage (expansion cracks) in addition to the increased depth of penetration. Silicon and calcium were still measurable at $22 \mathrm{~mm}$.

The ytrria-modified block exhibited the lowest depth of slag penetration at $12 \mathrm{~mm}$. SEM analyses showed that the silica did not react with the yttria and penetrate deeply into the block. The Plicast 99 sample modified with a $1 \%$ addition of yttria showed a reduction in the slag diffusion by approximately $27 \%$ compared to the unmodified sample. This is not as great a reduction as we had hoped, but it was encouraging. Figure 3 is a scanning electron image of the yttria-alumina-garnet (YAG) crystals that formed. The composition of the crystals was verified using X-ray diffraction analysis. A second experiment was done increasing the amount of yttria addition to $3 \%$ with the hope that the additional yttria would be enough to cause a passive layer to form. Figure 4 shows that the $3 \%$ addition of yttria only increased the number of individual YAG crystals formed.

In addition to the static corrosion tests, a dynamic test was started on a sample containing $1 \%$ yttria addition. Figure 5 is a graph comparing the average recession over time for the sample

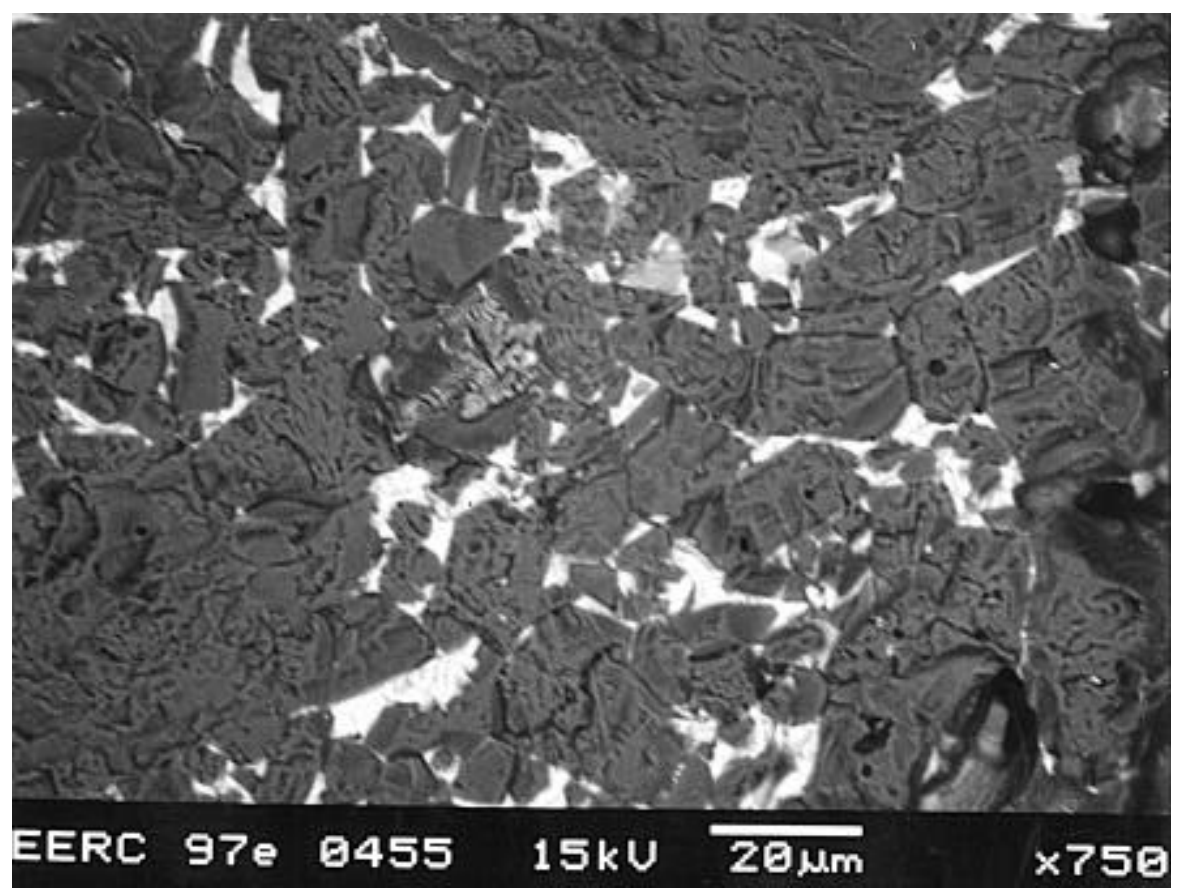

Figure 2. SEM image showing slag penetration into sample modified with $1 \%$ lanthana. 


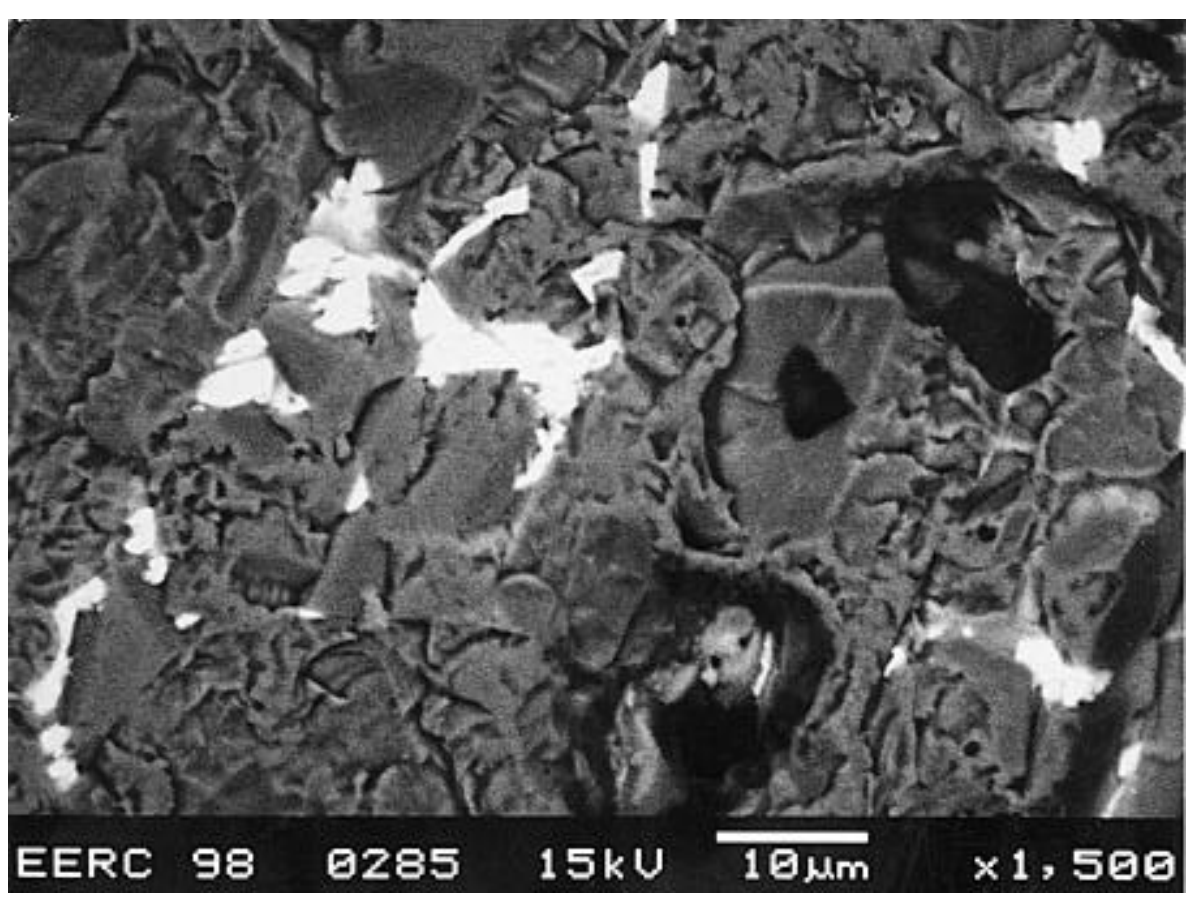

Figure 3. Yttria-alumina-garnet found in sample modified with $1 \%$ yttria.

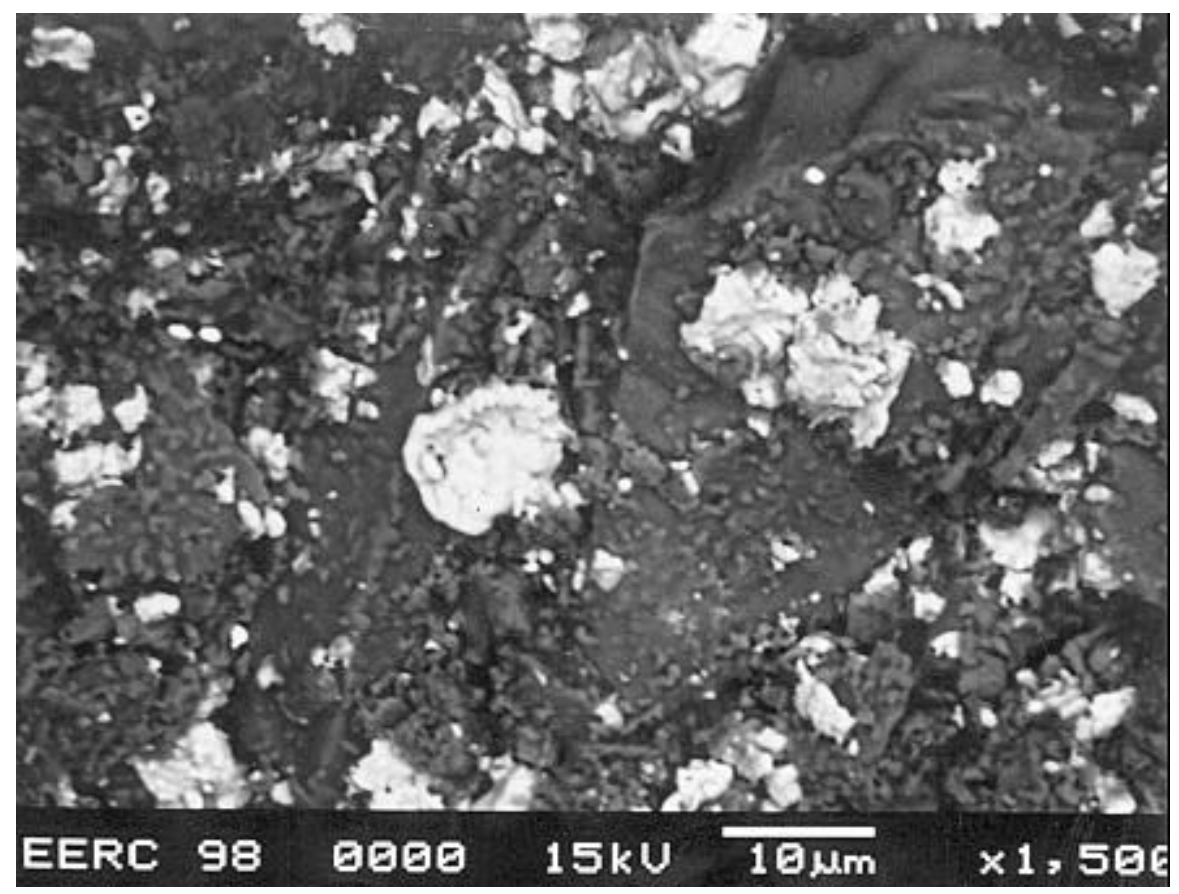

Figure 4. SEM image showing increased number of individual crystals in sample modified with $3 \%$ yttria. 


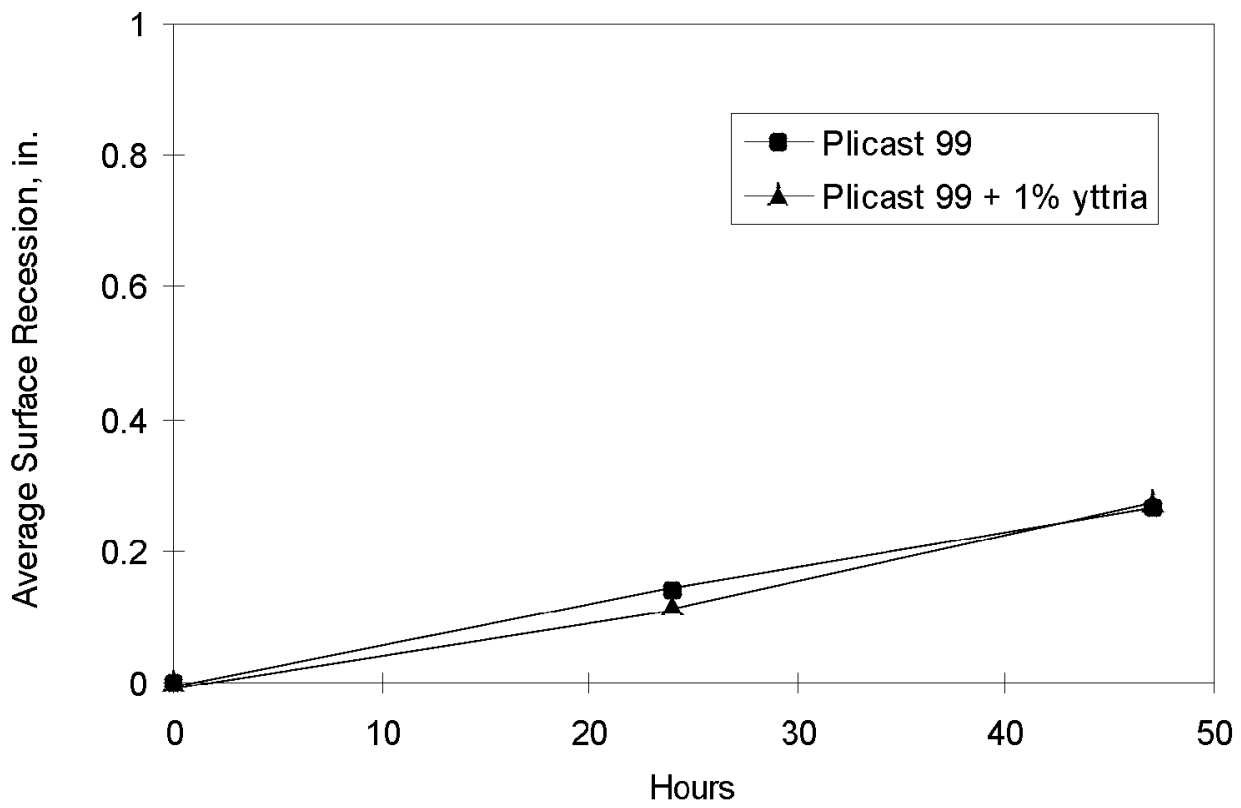

Figure 5. Graph comparing recession with time for sample of Plicast 99 modified with $1 \%$ yttria and Plicast 99 unmodified.

of Plicast 99 modified with $1 \%$ yttria and a sample of unmodified Plicast 99 . Because of mechanical problems with the furnace, the test was prematurely stopped after $471 / 2$ hours of slag feed. The base of the block modified with the $1 \%$ yttria was damaged when it was removed from the furnace. After the recession measurements were reviewed, it was apparent that the $1 \%$ yttria addition did not reduce the surface recession during a dynamic corrosion test enough to justify remaking the block and completing the 100-hour test.

\subsection{FUTURE WORK}

Two substrates of dense YAG were ordered to test its corrosion resistance in the presence of Illinois No. 6 slag at $1500^{\circ} \mathrm{C}\left(2732^{\circ} \mathrm{F}\right)$. If the YAG does not stand up well to corrosion, then we will abandon the attempts to form a passive YAG layer at the surface of the refractory blocks. The substrates are $3 / 4 \times 3 / 4 \times 1 / 4$ in. The YAG crystal will be placed on its side vertically in a platinum crucible, and enough slag will be poured into the crucible to cover the bottom half of the substrate. The crucible will then be placed in a furnace and slowly ramped to $1500^{\circ} \mathrm{C}\left(2732^{\circ} \mathrm{F}\right)$, where it will be held for 100 hours, then slowly cooled to room temperature. The substrate will be analyzed using SEM to determine surface recession and products of corrosion by the slag.

In addition to the YAG corrosion tests, experiments will be carried out using varying amounts of yttria (0.5 and $2.0 \mathrm{wt} \%$ ) to determine if it will help improve the sintering and corrodent diffusion rates in Plicast 99 refractory. Flexural strength of test bars will be determined 
after firing to temperatures of $1400^{\circ} \mathrm{C}\left(2550^{\circ} \mathrm{F}\right), 1500^{\circ} \mathrm{C}\left(2732^{\circ} \mathrm{F}\right)$, and $1600^{\circ} \mathrm{C}\left(2910^{\circ} \mathrm{F}\right)$. A total of five blocks for each wt\% and temperature range will be made (a total of 30 blocks). The test blocks will be $2 \times 2 \times 9$ in. The blocks will be fired to the predetermined temperature, held for 4 hours, then cooled to room temperature. A three-point modulus-of-rupture (MOR) test will be performed on the blocks using standard ASTM C133 procedure. 